\title{
Phaseolin Induction on Common-Bean Cultivars and Biological Control of Colletotrichum lindemuthianum 89 Race by Baccharis trimera (Less.) Dc.
}

Mario Cezar Pozza Junior ${ }^{{ }^{*}}$

https://orcid.org/0000-0001-6211-8192

\section{Jéssica Angela Pandini ${ }^{2}$}

https://orcid.org/0000-0001-7053-9966

Daiane Paulina Reichert Hein ${ }^{2}$

https://orcid.org/0000-0001-8006-9101
José Renato Stangarlin ${ }^{3}$

https://orcid.org/0000-0001-8601-9439

Roberto Luis Portz

https://orcid.org/0000-0002-1568-7330

Lucimar Pereira Bonett ${ }^{2}$

https://orcid.org/0000-0003-1827-2998

\section{José Aldemir da Silveira ${ }^{2}$}

https://orcid.org/0000-0003-1528-7027

${ }^{1}$ University of São Paulo, Luiz de Queiroz College of Agriculture, Piracicaba, São Paulo, Brazil; ${ }^{2}$ Paranaense University, Toledo, Paraná, Brazil; ${ }^{3}$ Western Paraná State University, Marechal Cândido Rondon, Paraná, Brazil; ${ }^{4}$ Federal University of Paraná, Palotina, Paraná, Brazil.

Editor-in-Chief: Alexandre Rasi Aoki

Associate Editor: Ivo Mottin Demiate

Received: 2020.12.29; Accepted: 2021.06.23.

*Correspondence: mariopozza.bio@gmail.com; Tel.: +55-19-982212655 (M.C.P.J.).

HIGHLIGHTS

- Baccharis trimera aqueous extracts can inhibit Colletotrichum lindemuthianun 89 race growth.

- C. lindemuthianum filtrate can be used as a phaseolin inductor on common bean.

- There is no evidence of phaseolin induction through application of aqueous extracts of $B$. trimera in common bean hypocotyls.

Abstract: The objective of this work was to evaluate the fungitoxic effect of the aqueous extracts of Baccharis trimera on the mycelial growth of Colletotrichum lindemuthianum 89 race, as well as its effect on the accumulation of phaseolin in hypocotyls of different cultivars and common bean varieties. It was obtained $20 \%$ aqueous extract from plants collected in municipalities of the Western Region of Paraná. Blocks containing $C$. lindemuthianum mycelium were transferred to Petri dishes containing medium with the different extracts and incubated at $25^{\circ} \mathrm{C}$. The colonies diameter was measured until the 12 th day. Effects of aqueous extracts on phaseolin production was evaluated in hypocotyls of Carioca, Cnpf 8104, Soberana, Tibatã, Uirapurú cultivars, as well as Rosinha and Vermelho varieties. Each one cultivar and variety hypocotyl was transferred separately to test tubes containing $500 \mu \mathrm{L}$ of $20 \%$ aqueous extracts. Sterile water, Bion ${ }^{\circledR}$, and UV was used as controls. The phaseolin production was measured in spectrophotometer [280 nm]. Results of the evaluation of the antifungal activity of aqueous extracts of Baccharis sp. specimens collected indicate that approximately $50 \%$ of the samples presented capacity to reduce between 74 and $92 \%$ of $C$. lindemuthianum growth. Cultivar Tibatã and Vermelho variety showed greater sensitivity over the applied 
treatments. Results of fungal filtrates and vegetal aqueous extracts presented a low capacity to induce the production of phaseolin in hypocotyls.

Keywords: Phytoalexins; Biocontrol; Resistance Induction; Anthracnose.

\section{GRAPHICAL ABSTRACT}

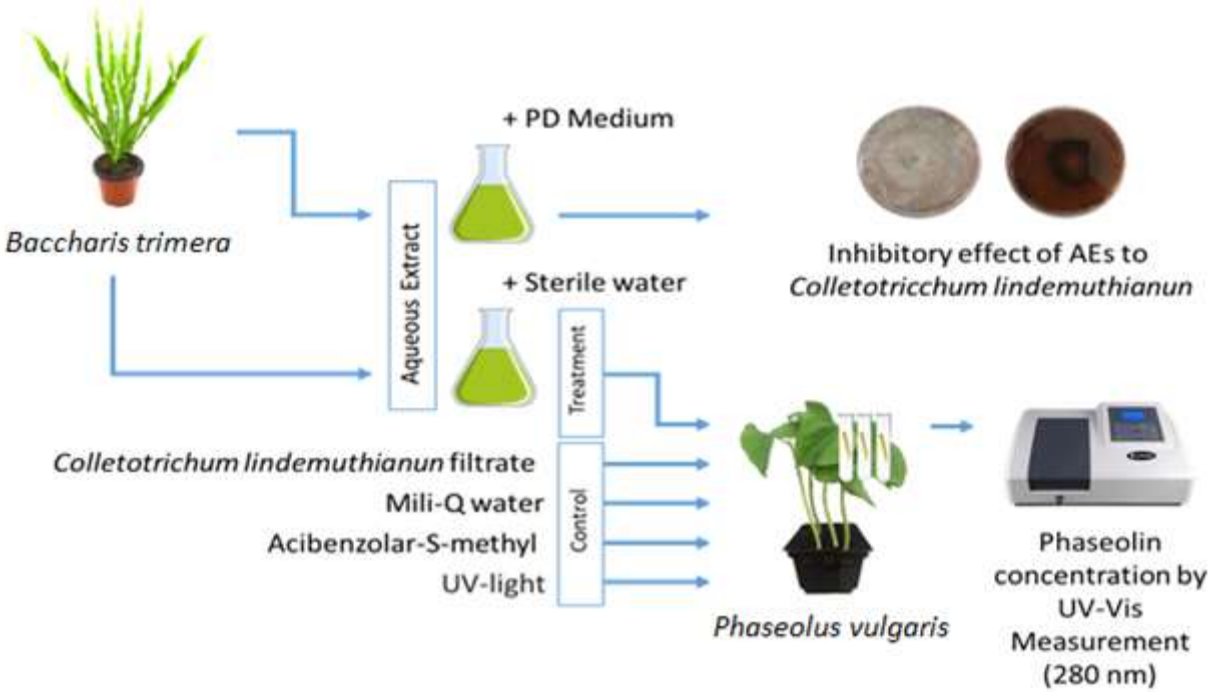

\section{INTRODUCTION}

The genus Phaseolus comprises approximately 55 species, but only five are cultivated, among which the common bean Phaseolus vulgaris L. [1]. In Brazil, the common bean mean about $85,5 \%$ of all bean crop production [2]. Brazil is the world's largest producer and consumer of common bean, representing one of the most economically and socially important crops (3). In 2019/2020 the harvest Brazilian country was 3.02 million tons of bean covered a 3 million ha area (4). By the other hand, common bean crops also means the basic economy of many small farms with less than 10 ha [5]. Moreover, being an excellent source of protein, it is one of the most important constituents of the Brazilian diet [6].

Genetic breeding programs has been promoting the development of several cultivars resistant to biotic and abiotic factors [7]. Improve new resistant cultivars represent an effective process to control diseases in the crop fields when compared to other methods like application of pesticides [8]. Although, great genetic variability of the pathogens has challenged genetic improvement projects [9].

Anthracnose is one of the most significant diseases in bean culture promoting total or partial loss of production [10]. The Colletotrichum lindemuthianum fungus is the causal agent of this disease and presents a great pathogenic variability throught 247 different races with 35 occurring particularly in Brazil [11]. In this context, one alternative way to solve the anthracnose problem is the induction of resistance in cultivars by the activation of latent defense mechanisms existing in plants, in response to treatment with biotic or abiotic agents [12]. Several chemical compounds provides by molecules of fungi, bacteria or also virus, can be applied on resistance induction once extracted from cells of microorganisms, filtered from cultures or living microorganisms $[13,14]$.

The synthesis of phytoalexins [phyton $=$ plant $/$ alexin $=$ repellent] is best studied defensive response to pathogens in plants, these compounds are formally known since 40s decade in Germany [15]and consists in a group of secondary metabolites produced by plants in response to infections by pathogens[16,17]. These natural products presents low molecular weight and are synthesized by plants in cells as a response to microbial infections (18), with the ability to interfere in the development of the pathogen [19].[Nowadays the importance of phytoalexins in a host-pathogen defense interaction also is recognized like an ecochemical natural products related to mediation of organisms interactions [20].

Phytoalexins belong to different chemical classes that include flavonoids, polyacetylenes and isoprenes, including terpenoids and steroids [21]. In addition, studies with crude extract and essential oil of medicinal plants have indicated their potential in the induction of phytoalexins, besides showing fungitoxic action [22]. The effects of phytoalexins also are known in human health, where some chemical classes can promote 
important effects in organism like antioxidant, antiaging, antitumor activities, or cardio and neuro protection [23].

Phaseolin is the main phytoalexin found in beans, this substance is produced when mature plants are attacked by fungi [24]. However in common bean seed case, the presence of phaseolin represents about $50 \%$ of total amount of protein [25]. So, in germinative stage this storage glycoproteins have the function of provide amino acids to seed [26]. The phaseolin protein show low enzymatic proteolysis and digestibility, but under certain conditions can be hydrolyzed, becoming small peptides with antioxidant and iron chelating potential $[27,28]$.

The medicinal plant Baccharis trimera (Less.) Dc., popularly known as "Carqueja", is one of the beststudied species in botanical, chemical and pharmacological terms [29]. In agriculture, the specie is explored by their allelopathic properties slowing the speed of seed germination [30] and for his fungitoxic action, inhibiting the mycelial growth of fungi [15]. In medicine B. trimera has proven action in the treatment of liver problems, due to the high antioxidant activity present in the crude extract of this species [20]. Furthermore, the specie present a high potential and importance to pharmacological researches $[1,31,32]$, due to several chemical classes found in your metabolism, like some categories of natural compounds, such as diterpenoids [17,33], flavonoids, [34,35], saponins [35-37], and essential oils [38].

In this sense, the objective of this work was to evaluate the phaseolin accumulation in common bean hypocotyls under influence of biotic and abiotic inductors, as well as the fungitoxic effect of applied aqueous extracts of $B$. trimera on the mycelial growth of $C$. lindemuthianum.

\section{MATERIAL AND METHODS}

\section{Obtaining aqueous extract of Baccharis trimera [AE]}

In order to obtain aqueous extracts (AEs) of $B$. trimera we collected 16 samples of fresh vegetative material in municipalities of western Paraná state: Jesuítas, Santa Helena, São Pedro do Iguaçu, Terra Roxa, Toledo and Vera Cruz do Oeste.

After being properly identified for the species, the samples were washed in running water and $50 \mathrm{~g}$ of the vegetative material was ground in $200 \mathrm{~mL}$ of Potato-Dextrose medium, without addition of Agar, for one minute in the blender. The filtration of the homogenates material was carried out in gauze, resulting in different AEs $(20 \%)$. Each one of $A E$ received $12 \mathrm{~g}$ of $\mathrm{L}^{-1}$ of agar and then autoclaved.

\section{Antifungal activity of AEs}

To evaluate a possible antifungal effect of AEs, we disposed micelial plugs of Colletotrichum lindemuthianum 89 Race $[\varnothing 5 \mathrm{~mm}$ ] in the center of Petri dishes containing Potato Dextrose Agar (KASVI®) culture media (Potato Dextrose Agar) with AEs. The plates were sealed with plastic film and incubated at 25 $\pm 2{ }^{\circ} \mathrm{C}$ in the dark. The evaluations were performed by measuring the diameter of the colonies (mean of two diametrically opposed measurements) for 12 days with a digital caliper. For each treatment with $A E$, it was used a total of five replicates and the negative control applied to assay was the culture media not containing $\mathrm{AE}$. To calculate the percentage inhibition of mycelial growth, we applied the formula proposed by Menten et al. [39].

\section{Obtaining the filtrate of $\mathrm{C}$. lindemuthianum}

To obtain the filtrate of $C$. lindemuthianum disks from the culture medium containing fungal mycelium were transferred to erlenmeyers, in $150 \mathrm{~mL}$ of Potato Dextrose Broth (KASVI®), and subsequently kept for nine days under orbital shaker at $120 \mathrm{rpm}$ in the dark at $25 \pm 2{ }^{\circ} \mathrm{C}$.

The mycelium was collected, washed in distilled water, and carefully separated from the culture medium residues. The pure mycelium obtained was macerated in a porcelain mortar, resulting in a powder after diluted in distilled water $(1: 4 \mathrm{~m} / \mathrm{v})$ and autoclaved. The resulting suspension was filtered on Whatman paper, with the aid of a vacuum pump and the obtained filtrate was frozen at $-70^{\circ} \mathrm{C}$.

\section{Effect of AEs on phaseolin production}

To evaluate the effect of AEs on phaseolin production, we adapted the methodology proposed by Dixon and coauthors [40]. Bean seeds of the cultivars Carioca, Cnpf 8104, Soberana, Tibatã, Uirapurú and Rosinha and Vermelho varieties were surfaccially disinfected in sodium hypochlorite [1\%] for five minutes and washed in sterilized distilled water. The seeds were then transferred to trays containing autoclaved sand and kept at 
$25 \pm 2{ }^{\circ} \mathrm{C}$ in the dark. After seven days of growth we detached hypocotyls segments of $5 \mathrm{~cm}$ long from the seedlings, washed them in sterile water and dried at room temperature on sterile filter paper. The hypocotyls of each cultivar were transferred separately to test tubes, containing $500 \mu \mathrm{L}$ of AEs (20\%) and the filtrate of C. lindemuthianum as treatments. We selected Acibenzolar-S-methyl (Bion®) plant defense inducer (160 ppm) as positive control and mili-Q water as negative control according to Brand and coauthors [41].

The test tubes were maintained at $25 \pm 2^{\circ} \mathrm{C}$ in the dark for 48 hours. After, the hypocotyls were removed and dried at room temperature on sterile filter paper. The hypocotyl base in contact with the solution of the treatments was excised and discarded, reducing possible interference in reading the results. The hypocotyls were transferred to test tubes containing $10 \mathrm{~mL}$ of ethanol (P.A.), kept at $4{ }^{\circ} \mathrm{C}$ for $48 \mathrm{~h}$ and shaken for one hour to extract phaseolin, which was measured indirectly at $280 \mathrm{~nm}$ [42].

All the phytoalexins induction experiment was realized in triplicates per treatment was used in a first trial, with all cultivars and bean varieties. For a second assay, the cultivars and varieties that had the highest values of phaseolin production were used. In addition to the other treatments, the hypocotyls were exposed to ultraviolet light for two hours.

\section{Statistical analysis}

The experimental design was completely randomized for mycelial growth and phaseolin induction assays. The data were submitted to analysis of variance, using the Sisvar Program for Windows version 4.0. [43].

\section{RESULTS AND DISCUSSION}

\section{Antifungal activity of AEs}

Antifungal activity assays with Baccharis trimera AEs (20\%) from specimens collected in the Western Region of Paraná indicate that about $50 \%$ of all materials presented capacity to reduce the growth of $C$. lindemuthianum in 74 and 92\% (Table 1).

Table 1. Effect of different Baccharis trimera AEs (B.c.) in the culture medium, on mycelial growth of Colletotrichum lindemuthianum, in millimeters and percentage, after 12 days of incubation. Averages indicated by the same letter do not differ by Tukey test, at $5 \%$ probability.

\begin{tabular}{|c|c|c|c|c|}
\hline Treatment & Site & Diameter $(\mathrm{mm})$ & Grouping & Growth (\%) \\
\hline B.c. -4 & Maripá & 5.00 & a & 8 \\
\hline B.c. -5 & Maripá & 5.00 & a & 8 \\
\hline B.c. -9 & Toledo & 5.00 & $a$ & 8 \\
\hline B.c. -16 & Toledo & 5.00 & a & 8 \\
\hline B.c. -8 & Toledo & 6.00 & $a b$ & 10 \\
\hline B.c. -10 & Toledo & 8.90 & $a b$ & 14 \\
\hline B.c. -12 & Toledo & 8.90 & $a b$ & 14 \\
\hline B.c. -15 & Toledo & 15.40 & c & 24 \\
\hline B.c. -17 & Toledo & 15.50 & c & 25 \\
\hline B.c. -3 & Maripá & 16.13 & $C^{*}$ & 26 \\
\hline B.c. -1 & Formosa do Oeste & 42.50 & $d$ & 67 \\
\hline B.c. -6 & Santa Helena & 42.83 & d & 68 \\
\hline B.c. -2 & Jesuítas & 43.63 & d & 69 \\
\hline B.c. -14 & Toledo & 48.20 & e & 77 \\
\hline B.c. -11 & Toledo & 48.33 & e & 77 \\
\hline B.c. -18 & Vera Cruz do Oeste & 57.88 & $f$ & 92 \\
\hline B.c. -7 & São Pedro & 58.17 & $f^{*}$ & 92 \\
\hline B.c. -13 & Toledo & 59.50 & $\mathrm{fg}$ & 94 \\
\hline Control & --- & 63.00 & $g$ & 100 \\
\hline Avareges & & 31.38 & & 46.37 \\
\hline CV [\%] & & 5.48 & & \\
\hline
\end{tabular}

${ }^{*}$ Baccharis sp. 
In this sense, we observed that B.c. -4 , B.c. -5 , B.c. -9 and B.c. -16 treatments had a higher inhibition rate over mycelial growth of Colletotrichum lindemuthianum, decreasing $92 \%$ in relation to the control. The other collected materials showed values between 0 and $33 \%$ in fungus growth reduction, indicating a low antifungal potential. The B.c.-7 and B.c. -13 treatments presented low antifungal action, inhibiting the fungal growth only in 8 and $6 \%$ respectively, not differing statistically from the control.

According to Milanesi and coauthors [21] and Delazer and coauthors [44], the concentration of $20 \%$ presented better antifungal effect against Colletotrichum sp. Stangarlin and coauthors [45] found that the plant partially inhibited the mycelial growth of Colletotrichum graminicola.

Moura and coauthors [46] related an antifungal potencial os $B$. trimera aquous extracts against Pseudocercospora vitis, Cercospora kaki, and Hemileia vastatrix, had been most effective when applied directely on the spores, damaging the germination of them. The same work still demonstrates the inefficiency of $B$. trimera to induce the production of phytoalexins in sorghum crop.

Pedrotti and coauthors [47] working with pure essential oils of $B$ trimera, found statistical differences among four concentrations when applied against Colletotrichum acutatum, where $0,07 \%$ (700 ppm) could reduce $100 \%$ of the mycelial growth until the 14 th day.

The variation of the fungitoxic effect of $B$. trimera extracts, found in the present work, demonstrates the possibility of genotypic and / or phenotypic variability of the materials collected in the cities sampled, as well as the importance of a more careful selection of the materials with purpose of use in the control of phytopathogens. Auler and coauthors [48], carrying out work with the reproductive and genetic aspects of $B$. trimera, verified that it presents genetic variability among and within the species.

The antifungal effect of Baccharis trimera and other medicinal plants was also confirmed by Bonaldo and coauthors [9] that obtained anthracnose reduction of about $50 \%$ in cotton affected by Colletotrichum gossypii var. cephalosporioides. Carreira [29], evaluated the essential oil biological activity of Baccharis trimera samples against Cladosporium sphaerospermum Penz, verifying variation in composition and antimicrobial activity of the volatile oil. This process was associated with the influence of environmental factors, include temperature variation and pluviometric indices, influencing the occurrence of terpenes [constituents of the volatile oils]. We believe that the terpenes could be volatilized to the atmosphere or leached to the soil, justifying a lower yield of the volatile oil of Baccharis trimera collected in the region where there was a higher temperature and a higher rainfall index.

It is important and necessary to proceed with the fractionation of the crude extracts in order to obtain the bioactive compounds, and also to establish the minimum concentration necessary for inhibiting $C$. lindemuthianun.

\section{Effect of AEs on phaseolin production}

The results of the average phaseolin production in hypocotyls of different bean cultivars and varieties treated with $B$. trimera AEs (Bc-13 and autoclaved and non-autoclaved $\mathrm{Bc}-9$ ) filtered from $C$. lindemuthianum, MiliQ and Bion® water are shown in Figure 1.

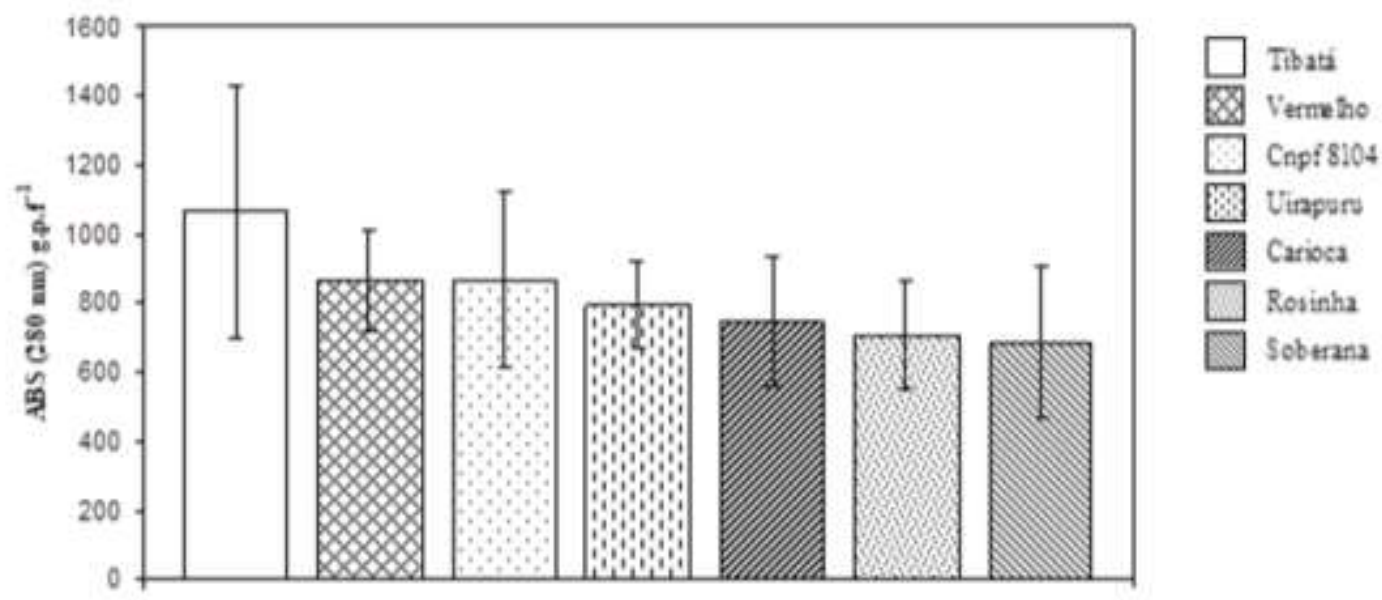

Cultivars and Varieties of Phaseolus vulgaris $L$.

Figure 1. Average of the phaseolin production in hypocotyls of different cultivars and varieties of bean (Phaseolus vulgaris $L$.) treated with inducers of biotic origin (AEs of $B$. trimera and $C$. lindemuthianum filtrates) and abiotic (Bion $\AA$ and water mili $-\mathrm{Q})$, measured by absorbance $(280 \mathrm{~nm})$ gram fresh weight ${ }^{-1}$ (gpf). Averages indicated by the same letter do not differ by Tukey test, at $5 \%$ probability. 
Although the results there was no significant difference between the values in the phaseolin production, among the cultivars and varieties submitted to the treatments, there was a greater variation in the production in cultivars Tibatã and Cnpf 8104 and in the Vermelho variety. Based on these data, the cultivar Tibatã and the Vermelho variety were selected and submitted to a new test with the same treatments, plus UV-light treatment (Figure 2).

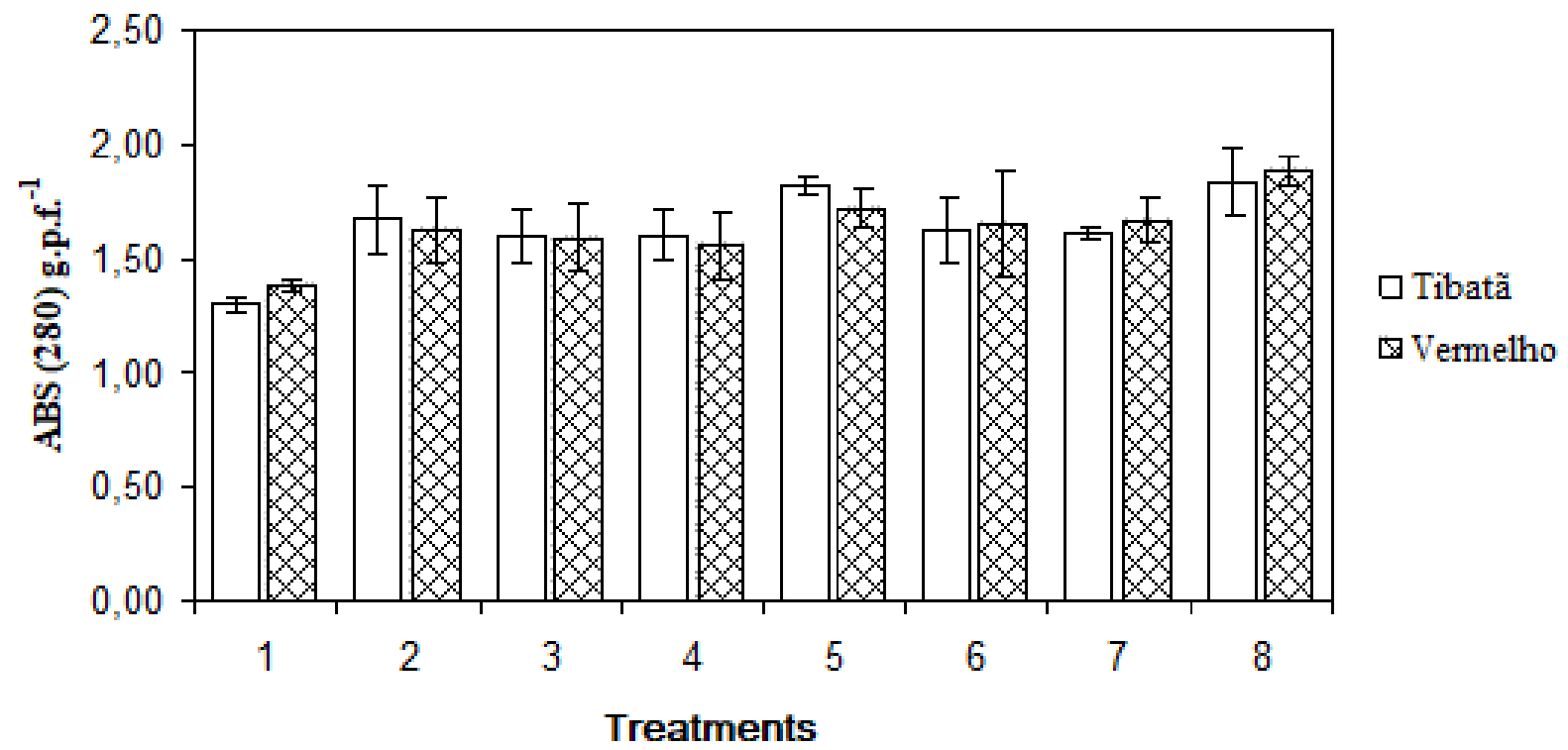

Figure 2. Average of the phaseolin production in hypocotyls of the cultivar Tibatã and of the Red variety treated with different inducers of biotic and abiotic origin, measured by the absorbance $(280 \mathrm{~nm})$ gram of fresh weight-1 (g.p.f.). (1) autoclaved Bc-9, (2) non-autoclaved Bc-9, (3) autoclaved Bc-9, (5) non-autoclaved Bc-9, (6) filtrate of C. lindemuthianum, (7) Bion $\AA$, (8) UV light. Averages indicated by the same letter are not significant by Scott-Knott test at $5 \%$ probability.

The phaseolin production average in hypocotyls of Tibatã cultivar indicated a significant difference between autoclaved and non-autoclaved B.c.-13 treatments. This result suggests that autoclavation process reduce the ability of these AEs to induce the production of this phytoalexin. On the other hand, the autoclaved B.c.-13 treatment acted apparently as an antioxidant reducing phaseolin production at lower levels of those induced with water treatment. The autoclaved and non-autoclaved B.c.-9 treatments did not present a reduction action on phaseolin production.

The filtrate of $C$. lindemuthianum and the treatment with UV light presented the highest averages for phaseolin production, being superior to the Bion $\circledast$ plant defense inducer and the other treatments. Wulff and Pascholati [49] testing the autoclaved filtrate of Saccharomyces cerevisiae, verified that there was a greater accumulation of phytoalexins in sorghum mesocotils.

Stangarlin and coauthors [45] testing the accumulation of deoxyanthiocyanidins in sorghum mesocotyls, observed that the treatment with the pathogen Colletotrichum graminicola obtained a greater accumulation of metabolites related to plant defense. Bonaldo and coauthors [50] found that the highest production of phytoalexins deoxyanthyanidins in sorghum were promoted by the pathogen Colletotrichum sublineolum.

Solino and coauthors [22] evaluating the induction of phaseolin, gliceonin and deoxyanthocyanidins by filtrates of saprophytic fungi species Curvularia inaequalis, Pseudobitritis terrestris, Memnomiella echinata $e$ Curvularia eragrostidis, obtained a phaseolin increment of $9,8,9$ and $7 \%$ when compared to control.

When Baldin and coauthors [51] tested propolis ethalnolic extracts provide from three different places from west of Paraná state, at six concentrations between 0,05 at $5 \%$, the team obtained a three linear results about pheseolin production at Carioca bean ( $P$. vulgaris L. IPR-Colibri variety), increasing the production of phaseolin on every treatments applied. The use of propolis like phytoalexin inductor also was verified by Jaski and coauthors [52] where these treatment presented a direct correlation between propolis concentration and phaseolin production on common bean with high levels of induction.

Tibatã cultivar and the Vermelho variety presented the highest values for its induction when submitted to the treatment with inductors of biotic and abiotic origin and compared to the other materials evaluated, being necessary to know the genetic characteristics of the plant used to obtain extracts with greater possibility to induce the production of phytoalexins. In order to know major datas about chemical characteristics of the 
high diversity of these compounds, molecular methods must be applied, thus allowed elucidate the mechanisms involved on biosynthesis and regulation of phytoalexins in front of these inductors.

\section{CONCLUSION}

Results from the evaluation of the antifungal activity of AEs from Baccharis sp. specimens collected in the Western Region of Paraná indicate the specie have the capacity to reduce $C$. lindemuthianum growth.

The Tibatã cultivar and Vermelho variety stand out above the others cultivars about phaseolin production independent of inductor applied. However, the obtained results on the production of phaseolin in hypocotyls of these two selected cultivar and variety indicate the biological treatments $B$. trimera AEs and $C$. lindemuthianun filtrate such as a lower phytoalexin inductors to common bean.

Funding: This research was funded by Paranense University.

Acknowledgments: The authors are grateful to received funds by the Paranaense University - Toledo, needed to conclusion of this work. The authors declare that they have no conflict of interest.

Conflicts of Interest: The authors declare no conflict of interest.

\section{REFERENCES}

1. Costa J, Vieira N. Qualidade, classificação comercial, e manejo pós-colheita. In: Yokoyama LP; Stone LF. Feijão EA e, editor. Cultura do feijoeiro no Brasil: Características de produção. 1st ed. Santo Antônio de Goiás: Embrapa Arroz e Feijão; 2000.

2. EMBRAPA Secretaria de comunicação. Balanço comercial Embrapa 2016. Brasília; 2017.

3. Borém A, Carneiro J. A cultura. In: Borém A (Ed.) Melhoramento de espécies cultivadas. 1st ed. Viçosa: Editora UFV, 2006.

4. CONAB. Acompanhamento da safra brasileira de grãos. 7 - SAFRA 2019/20-N 3 -Terceiro levantamento-dez. 2019, 2019.

5. Broughton WJ, Hernández G, Blair M, Beebe S, Gepts P, Vanderleyden J. Beans (Phaseolus spp.) - Model food legumes. Plant and Soil. 2003; 252(1):55-128.

6. Torres LMB, Gamberini MT, Roque NF, Lima-Landman MT, Souccar C, Lapa AJ. Diterpene from Baccharis trimera with a relaxant effect on rat vascular smooth muscle. Phytochemistry. 2000; 55(6):617-9.

7. Lorenzi H, Matos F. Plantas medicinais no Brasil: Nativas e exóticas. São Paulo: Instituto Plantarum, 2002.

8. Mundt CC. Durable resistance: A key to sustainable management of pathogens and pests. Infection, Genetics and Evolution. 2014; 27(1)446-55.

9. Bonaldo SM, Santos BT, Bulhões CC, Bonaldo SM. Inducing resistance in cotton against Colletotrichum gossypii var. cephalosporioides with essential oils. Sci Electronic Arch. 2016;9(5)45-50.

10. Bianchini A, Maringoni A, Carneiro S. Doenças do feijoeiro (Phaseolus vulgaris). In. Kimati H, Amorim L, Rezende JAM, Bergamin Filho A, Camargo LEA. Manual de Fitopatologia. 1st ed. São Paulo: Agronomica Ceres, 2005.

11. Nunes M, Gonçalves-Vidigal M, Lacanallo G, Coimbra G. Comprehension of genetic variability and virulence of Colletotrichum lindemuthianum in common bean. 51th BIC Meeting. 2013.

12. Hammerschmidt H, Dann E. Induced resistance to disease. In: Raton B. Environmentally Safe Approaches to Crop Disease Control. 1st ed. CRC Press, 1997.

13. Rizzini C. Tratado de fitogeografia do Brasil aspectos ecológicos sociológicos e florísticos. 1st ed. Rio de Janeiro: Âmbito Cultural, 1997.

14. Oliveira MDM, Varanda CMR, Félix MRF. Induced resistance during the interaction pathogen $x$ plant and the use of resistance inducers. Phytochem. Lett. 2016;15(1)152-8.

15. Paxton JD. Phytoalexins - A Working Redefinition. J Phytopathol. 1981; 101(2)106-9.

16. Zuanazzi J, Montanha J. Flavonóides. In: Simões CMO, Schenkel EP, Gosman G, Mello JCP, Mentz LA. Farmacognosia da planta ao medicamento. 1st ed. Florianópolis:UFSC, 2004.

17. Taiz L, Zeiger E. Fisiologia vegetal. 4th ed. Porto Alegre: Artmed, 2009.

18. Pascholati S, Leite B. Mecanismos de resistência. In: Bergamin Filho A, Kimati H, Amorin L. Manual de Fitopatologia. São Paulo:Ceres, 1995.

19. Santos BA, Zambolim L, Ventura JA, Francisco \&, Vale XR. Severidade de isolados de Fusarium subglutinans fs pananas sensíveis e resistentes ao Benomyl em abacaxizeiro. Fitopatol Bras. 2002;27(1):101-3.

20. Kömíves T, Király Z. Disease resistance in plants: The road to phytoalexins and beyond. Ecocycles, 2019;5(1):712.

21. Milanesi $P$, Blume $E$, Muniz $S$, Brand $S$, Jungles $E$, Manzoni $C$, et al. Ação fungitóxica de extratos vegetais sobre o crescimento micelial de Colletotrichum gloeosporioides. Rev da FZVA Uruguaiana, 2009; 16(1):1-13. 
22. Solino AJDS, Schwan-Estrada KRF, Oliveira JSB, Ribeiro LM, Saab MF. Accumulation of phytoalexins in beans, soybeans and sorghum by fungal filtrates. Rev Caatinga. 2017; 30(4):1073-8.

23. Jeandet P, Courot E, Clément C, Ricord S, Crouzet J, Aziz A, Cordelier, S. Molecular Engineering of Phytoalexins in Plants: Benefits and Limitations for Food and Agriculture. J Agr Food Chem. 2017; 65(1):2643-4.

24. Picoli T, Massako T, Augusto S, Nascente P, Nascimento $S$. Efeito do óleo essencial de Baccharis trimera (Carqueja) frente a leveduras. $16^{\circ}$ - Congresso de Iniciação Científica. Pelotas, 2007.

25. Yao Y, Hu Y, Zhu Y, Gao Y, Ren G. Comparisons of phaseolin type and $\alpha$-amylase inhibitor in common bean (Phaseolus vulgaris L.) in China. Crop J. 2016; 4(1):68-72.

26. Thibeault J, Church J, Ortiz-Perez B, Addo S, Hill S, Khalil A, et al. Analyzing bean extracts using time-dependent SDS trapping to quantify the kinetic stability of phaseolin proteins. Biochem Biophys Res Commun. 2017; 491(4):994-9.

27. Hayat I, Ahmad A, Masud T, Ahmed A, Bashir S. Nutritional and Health Perspectives of Beans (Phaseolus vulgaris L.): An Overview. Crit Rev Food Sci Nutr. 2014; 54(5):580-92.

28. Mecha E, Eduardo Figueira M, Carlota Vaz Patto M, do Rosário Bronze M. Two Sides of the Same Coin: The Impact of Grain Legumes on Human Health: Common Bean (Phaseolus vulgaris L.) as a Case Study. Legume Seed Nutraceutical Research. IntechOpen, 2019.

29. Carreira R. Baccharis trimera (Less ) DC(Asteraceae) estudo comparativo dos óleos voláteis atividade biológica e crescimento de estacas de populações ocorrentes em áreas de Cerrado e Mata Atlântica. Botanical Institute of São Paulo Envirnmental Secretary; 2007.

30. Castro H, Ferreira F. Contribuição ao estudo das plantas medicinais: CARQUEJA (Baccharis genistelloides). Viçosa, 2000. 102 p.

31. Romeiro R, Garcia F. Indução de resistência em plantas a patógenos por elicitores de natureza bacteriana. In: Bettiol W, Morandi MAB. Biocontrole de doenças de plantas uso e perspectivas. $1^{\text {st }}$ ed. Jaguariuna:Embrapa Meio Ambiente, 2009.

32. Sabir SM, Athayde ML, Boligon AA, Rocha JBT. Antioxidant activities and phenolic profile of Baccharis trimera, a commonly used medicinal plant from Brazil. South African J Bot. 2017; 113(1):318-23.

33. Herz W, Pilotti AM, Söderholm AC, Shuhama I, Vichnewski W. New ent-Clerodane-Type Diterpenoids from Baccharis trimera. J Org Chem. 1977; 42(24):3913-7.

34. Snyder BA, Nicholson RL. Synthesis of phytoalexins in sorghum as a site-specific response to fungal ingress. Science. 1990; 248(4963):1637-9.

35. Gené RM, Cartañá C, Adzet T, Marín E, Parella T, Cañigueral S. Anti-inflammatory and analgesic activity of Baccharis trimera: Identification of its active constituents. Planta Med. 1996; 62(3):232-5.

36. Chicourel E, Pimenta D, Jorge L, Ferro V. Contribuição ao conhecimento analítico de três compostas medicinais. Rev Bras Farmacogn. 1998; 7-8(1):59-66.

37. de Bona CM, Biasi LA, Nakashima T, Zanette F, Corrêa Júnior C. Carqueja Cultive essa idéia. 1st ed. Curitiba: UFPR, 2002.

38. Agostini F, Santos ACA, Rossato M, Pansera MR, Zattera F, Wasum R, et al. Estudo do óleo essencial de algumas espécies do gênero Baccharis (Asteraceae) do sul do Brasil. Rev Bras Farmacogn. 2005; 15(3):215-9.

39. Menten J, Machado C, Minussi E, Castro C, Kimati H. Efeito de alguns fungicidas no crescimento micelial de Macrophomina phaseolina (Tass ) Goid "in vitro". Fitopatol Bras. 1976; 1:57-66.

40. Dixon RA, Dey PM, Lawton MA, Lamb CJ. Phytoalexin Induction in French Bean. Plant Physiol.1983;71(2):251-6.

41. Brand S, Blume E, EMM F, Dressler V, Sheeran M, Antonello L, et al. Acibenzolar-S-Metil na indução de fitoalexinas em Phaseolus vulgaris. IX CONAFE. Campinas; 2008.

42. Bailey JA, Burden RS. Biochemical changes and phytoalexin accumulation in Phaseolus vulgaris following cellular browning caused by tobacco necrosis virus. Physiol Plant Pathol. 1973; 3(2)171-7.

43. Ferreira D. Análises estatísitcas por meio do Sisvar para Windows versão 4.0. Reunião Anual da Regional Brasileira da Sociedade Internacional de Biometria. São Carlos; 2000.

44. Delazer M, Scopel S, Magrini F, Pansera M, Camatti-Sartori V, Ribeiro R. Baccharis trimera no controle in vitro de fitopatógenos. XLII Congresso Brasileiro de Fitopatologia. 2009.

45. Stangarlin J, Schwan-Estrada K, Cruz M, Nozaki M. Plantas Medicinais e Controle Alternativo de Fitopatógenos. Biotecnol Ciência Desenvolv. 1999; 11(3)16-21.

46. Moura GS, Franzener G, Stangarlin JR, Schwan-Estrada KRF. Atividade antimicrobiana e indutora de fitoalexinas do hidrolato de carqueja (Baccharis trimera (Less.) DC.). Rev Bras Plantas Med. 2014; 16(1):309-15.

47. Pedrotti C, Silva Ribeiro RT da, Schwambach J. Control of postharvest fungal rots in grapes through the use of Baccharis trimera and Baccharis dracunculifolia essential oils. Crop Prot. 125:104912, 2019. 
48. Auler N, Battistin A, Reis M. Número de cromossomos, microsporogênese e viabilidade do pólen em populações de carqueja (Baccharis trimera (Less.) DC.) do Rio Grande do Sul e Santa Catarina. Rev. Bras. PI. Med. 2006; 8(2):55-63.

49. Wulff NA, Pascholati SF. Preparações de Saccharomyces cerevisiae elicitoras de fitoalexinas em mesocótilos de sorgo. Sci Agric. 1998; 55(1):138-43.

50. Bonaldo S, Schwan-Estrada K, Stangarlin J, Tessmann D, Scapim C. Fungitoxicidade, atividade elicitora de fitoalexinas e proteção de pepino contra Colletotrichum lagenarium, pelo extrato aquoso de Eucalyptus citriodora. Fitopatol Bras. 2004; 29(2):128-34.

51. Baldin D, Scariot E, Telaxka F, Jaski J, Franzener G, Moura G, et al. Indução de faseolina em feijão e na atividade antibacteriana sobre Xanthomonas axonopodis pv. phaseoli pelo extrato etanólico de própolis | Cadernos de Agroecologia. 2014; 9(1).

52. Jaski JM, Telaxka FJ, Moura GS, Franzener G. Green propolis ethanolic extract in bean plant protection against bacterial diseases. Cienc. Rural. 2019; 49(6).

cC (7) (5) 2021 by the authors. Submitted for possible open access publication under the terms and (1) conditions of the Creative Commons Attribution (CC BY NC) license (https://creativecommons.org/licenses/by-nc/4.0/). 